\title{
Organ Measurements Laterality
}

National Cancer Institute

\section{Source}

National Cancer Institute. Organ Measurements Laterality. NCI Thesaurus. Code

C119886.

A qualifier for the side of the body the org an measurements assessment is performed. 